\title{
Microbial mediation of 'reactive' nitrogen transformations in a temperate lagoon
}

\author{
Iris Cofman Anderson ${ }^{1, *}$, Karen J. McGlathery ${ }^{2}$, Anna Christina Tyler ${ }^{2}$ \\ ${ }^{1}$ School of Marine Science, Virginia Institute of Marine Science, College of William and Mary, Gloucester Point, \\ Virginia 23062, USA \\ ${ }^{2}$ Department of Environmental Sciences, Clark Hall, University of Virginia, Charlottesville, Virginia 22903, USA
}

\begin{abstract}
Coastal lagoons positioned along the land margin may play an important role in removing or transforming 'reactive' nitrogen during its transport from land to the ocean. Hog Island Bay is a shallow, coastal lagoon located on the ocean-side of the Delmarva Peninsula in Virginia (USA). External nitrogen inputs are derived primarily from agriculturally enriched groundwater, and these support, in part, the high production of benthic macroalgae and microalgae as the dominant primary producers. This study focuses on processes in the water column (phytoplankton and bacterial) and in the sediments (microalgal and bacterial) responsible for transformations of dissolved inorganic and organic nitrogen (N). Sediment-water exchanges of dissolved inorganic and organic $\mathrm{N}$ were measured as well as sediment gross and net mineralization of organic $\mathrm{N}$. Net changes in dissolved inorganic nitrogen concentrations were greater in the water-column incubations than in the incubations including sediment and water. In the water column, metabolism resulted in net uptake of $\mathrm{NH}_{4}{ }^{+}$during all seasons and in net uptake of $\mathrm{NO}_{3}{ }^{-}$during most seasons. In the sediments, gross mineralization, which ranged from 0.9 to $6.5 \mathrm{mmol} \mathrm{N} \mathrm{m}^{-2} \mathrm{~d}^{-1}$, resulted in short turnover times $(<1 \mathrm{~d})$ for the sediment $\mathrm{NH}_{4}{ }^{+}$pool; however, sediment-water fluxes of both $\mathrm{NH}_{4}{ }^{+}$and $\mathrm{NO}_{3}{ }^{-}$were either negligible or directed into the sediments. The $\mathrm{NH}_{4}{ }^{+}$produced by gross mineralization was rapidly consumed in the dark. Biological processes potentially responsible for removal of sediment $\mathrm{NH}_{4}{ }^{+}$and $\mathrm{NO}_{3}{ }^{-}$include coupled nitrificationdenitrification, dark uptake by benthic microalgae, and immobilization by heterotrophic bacteria. In the absence of dark uptake of $\mathrm{NH}_{4}{ }^{+}$by benthic microalgae, potential nitrification calculated as the difference between gross mineralization and $\mathrm{NH}_{4}{ }^{+}$fluxes, would range from 1.5 to $6.4 \mathrm{mmol} \mathrm{N} \mathrm{m} \mathrm{d} \mathrm{d}^{-1}$, similar to rates observed in a range of other systems. Similarly, potential denitrification rates estimated as the difference between calculated nitrification rates and measured $\mathrm{NO}_{3}{ }^{-}$fluxes would vary from 1.88 to $5.16 \mathrm{~mol} \mathrm{~N} \mathrm{~m}^{-2} \mathrm{~d}^{-1}$ and fall within the range of rates reported for similar systems. However, since calculated benthic microalgal $\mathrm{N}$ demand (2.51 to $16.11 \mathrm{mmol} \mathrm{N} \mathrm{m}^{-2} \mathrm{~d}^{-1}$ ) exceeded $\mathrm{NH}_{4}{ }^{+}$release by gross mineralization at all sites and during all seasons, this suggests that dark benthic microalgal uptake was likely to be an important sink for mineralized N. Finally, sediment bacterial N immobilization may also be important given the relatively high $\mathrm{C} / \mathrm{N}$ of sediment organic matter. These estimates of the potential consumptive processes for mineralized sediment $\mathrm{N}$ indicate that the lagoon is likely to retard and or remove 'reactive' $\mathrm{N}$ during its transport to the coastal ocean.
\end{abstract}

KEY WORDS: Lagoon $\cdot$ Nitrogen $\cdot$ Macroalgae $\cdot$ Benthic $\cdot$ Microalgae $\cdot$ Nitrification $\cdot$ Denitrification $\cdot$ Mineralization

\section{INTRODUCTION}

Coastal lagoons represent a common feature along the land margin worldwide and are especially common along the east coast of the US (Nixon 1982, Boynton
1996). These lagoons are typically shallow and well mixed and receive little riverine freshwater input (Boynton 1996). Often the major source of freshwater is surface-water runoff, atmospheric deposition, or groundwater from shallow aquifers, which are suscep- 
tible to contamination by nutrients, especially 'reactive $\mathrm{N}^{\prime}$ (Giblin \& Gaines 1990). We use the term 'reactive N' here to refer to dissolved inorganic nitrogen (DIN) and dissolved organic nitrogen (DON) species, which may be readily used to support primary or secondary production in sediments or the water column. In this study we estimated rates of biogeochemical processes potentially responsible for transformations and removal of $\mathrm{N}$ from the lagoon.

Since most of the surface area of coastal lagoons is in the littoral zone, they often support high levels of primary production by benthic microalgae and by macrophytes such as seagrasses or macroalgae in addition to phytoplankton (Sfriso et al. 1992, McGlathery et al. 2001). Nutrient enrichment often leads to a proliferation of ephemeral benthic macroalgae (Sfriso et al. 1992, Valiela 1992, 1997, Duarte 1995). In nutrientenriched lagoons blooms of macroalgae may be followed by dystrophic events during which the bloom crashes releasing large amounts of DIN and DON (Viaroli et al. 1996, Tyler et al. 2001). Respiration of the dissolved organic matter (DOM) released during macroalgal senescence often results in hypoxia in both sediments and the water column. In addition, toxic levels of sulfide may accumulate, killing benthic infauna (Bartoli et al. 1996, Viaroli et al. 1996, Herbert 1999).

The large surface-area-to-volume ratio of most coastal lagoons increases the importance of benthic/ pelagic coupling and of biological transformations of 'reactive' $\mathrm{N}$ and carbon in the sediments relative to deeper estuaries. In highly productive shallow lagoons and embayments there are typically large diurnal shifts in dissolved oxygen (DO), which potentially affect microbial processing of both DIN and DON in the sediments (Bartoli et al. 1996, Rysgaard at al. 1996, Sundback et al. 2000, An \& Joye 2001). The impacts of nutrient export across the land margin on the coastal ocean will depend upon processes that retard or remove $\mathrm{N}$ within embayments such as coastal lagoons (An \& Joye 2001).

This study was performed in Hog Island Bay (HIB), a coastal lagoon on the ocean-side of Virginia's Delmarva Peninsula. Agriculture, which occupies approximately $55 \%$ of the watershed, has seriously impacted groundwater quality (Bohlke \& Denver 1995). The shallow groundwater aquifer is the major source of freshwater and probably also of DIN to HIB, with concentrations of nitrate as high as $3.4 \mathrm{mM}$ (Reay et al. 1992, Hamilton \& Helsel 1995, Neikirk 1996, Anderson et al. 1997). Nitrate released during spring and early summer, primarily in base flow from the shallow aquifer, is immobilized both by benthic microalgae and by the opportunistic macroalgae Gracilaria tikvahiae and Ulva lactuca, which often form extensive mats in the mid-lagoon during spring and early summer.
McGlathery et al. (2001) in a study concurrent with that reported here measured both production and biomass for each of the autotrophic communities in HIB. Macroalgal biomass was highly variable, ranging from 0 to $650 \mathrm{gdw}$ ( $\mathrm{g}$ dry weight) $\mathrm{m}^{-2}$. The macroalgal bloom, which peaked in June with highest biomass at the mid-lagoonal site, assimilated 3.1 to $9.5 \mathrm{mmol} \mathrm{N}$ $\mathrm{m}^{-2} \mathrm{~d}^{-1}$, with a total accumulated $\mathrm{N}$ pool prior to collapse of the bloom of $129 \mathrm{mmol} \mathrm{N} \mathrm{m}{ }^{-2}$ at near-shore sites and $571 \mathrm{mmol} \mathrm{N} \mathrm{m}^{-2}$ at mid-lagoon sites. Over a several-year period, water-column chlorophyll a $(\mathrm{chl} a)$ in HIB ranged from a low of $<1 \mu \mathrm{g} \mathrm{l}^{-1}$ in October to a high of $19 \mathrm{\mu g} \mathrm{l}^{-1}$ in both February and mid-summer, suggesting that phytoplankton are likely to play an important role in immobilizing $\mathrm{N}$ within this system mainly during winter and mid-summer. The benthos was net autotrophic during May, August, and October, whereas the pelagic community was net autotrophic in August, but net heterotrophic in spring and fall. Contribution by the microalgal community to benthic production peaked in August and was highest at sites furthest from the mainland. Nutrient retention in the macroalgal community was temporary. At the midlagoon shoal site algal-bound $\mathrm{N}$ was rapidly released as DON and DIN during mid-summer when the macroalgal bloom senesced and decomposed (Tyler et al. 2001). Previous work has shown that on an annual basis the extensive salt marshes that border the lagoon are not a net source of either DIN or DON to HIB (Neikirk 1996). More detailed information on uptake and transformations of $\mathrm{N}$ and carbon by macroalgae in HIB are reported by McGlathery et al. (2001) and Tyler et al. (2001).

The objectives of the study described here were to determine the fate of DIN and DON derived from upland sources, decomposition of macroalgae, and sediment remineralization in HIB. We assessed processes, both autotrophic and heterotrophic, that remove DIN (immobilization by benthic microalgae or phytoplankton and bacteria and coupled nitrification/denitrification) relative to processes that produce DIN (mineralization) within both the water column and the lagoonal sediments.

\section{SITE DESCRIPTION}

Hog Island Bay is located within the Virginia Coast Reserve (VCR), a Long Term Ecological Research (LTER) site (Fig. 1). The lagoon extends over an area of approximately $100 \mathrm{~km}^{2}$. It is both surrounded and intersected by extensive areas of salt marshes and mudflats, which are drained by a network of intertidal creeks. Relict oyster reefs are common throughout the lagoon. Average water depth within the lagoon is 1 to 
$2 \mathrm{~m}$ at mean low water (MLW); the semidiurnal tidal range is $1.1 \mathrm{~m}$ along the barrier islands and $1.5 \mathrm{~m}$ along the mainland edge (Santos 1996). A transect, consisting of 3 sites (Fig. 1), was established across HIB from the mainland border to Hog Island, a barrier island, a distance of approximately $10 \mathrm{~km}$. The Creek site was located at the mouth of a tidal creek draining salt marsh on the mainland border of the lagoon; the Shoal site was located mid-lagoon adjacent to relict oyster reefs; the Hog site was located adjacent to Hog Island in a back-barrier embayment. The average water depth at the 3 sites is approximately $0.5 \mathrm{~m}$ (MLW).

Studies were conducted seasonally in October 1997, and in May, July, and August 1998. The July study was performed immediately following the collapse of a large macroalgal bloom at the Shoal site; the August study was conducted 5 wk later. Measurements included sediment-water $\mathrm{N}$ (inorganic and organic) fluxes, gross $\mathrm{N}$ mineralization, and sediment characterization (extractable nutrients, chl $a$, organic content, total $\mathrm{C}$, total $\mathrm{N}$ [TN]). McGlathery et al. (2001) report DIC fluxes collected concurrently at the same sites. Water samples collected across the HIB transect were analyzed for chl $a$, DIN and DON.

\section{MATERIALS AND METHODS}

Sediment characterization. Dissolved inorganic nitrogen (DIN) analyses: Sediment was extracted with a volume of $\mathrm{KCl}$ (2 M) equal to twice the sediment volume, shaken on a rotary shaker for $1 \mathrm{~h}$ at room temperature, and centrifuged. Supernatants were filtered (Gelman Supor $0.45 \mu \mathrm{m}$ filters) and stored frozen in sterile Whirlpak ${ }^{\circledR}$ bags until analyzed. $\mathrm{NH}_{4}{ }^{+}$was determined by the technique of Solorzano (1969). Nitrate $\left(\mathrm{NO}_{3}^{-}\right)$was reduced to nitrite $\left(\mathrm{NO}_{2}^{-}\right)$ using a cadmium reduction column and analyzed by diazotization using an Alpkem 'Flow Solution' auto analyzer (Perstorp 1992).

Bulk sediment properties: Core sections (25.5 $\mathrm{cm}^{2}$ cross sectional area) cut at 2, 3, and $5 \mathrm{~cm}$ intervals to a depth of $10 \mathrm{~cm}$ were dried at $60^{\circ} \mathrm{C}$ to constant weight and reweighed to determine \% water, dry weight, and dry bulk density. Dry soils were combusted at $500^{\circ} \mathrm{C}$ for $5 \mathrm{~h}$ and reweighed to determine organic content.

Total $\boldsymbol{C}$ and $\mathbf{N}$ : Dried sediment from 0 to 2,2 to 5 , and 5 to $10 \mathrm{~cm}$ core sections were ground in a Wiley mill (\#40 screen), weighed into ashed silver cups and acidified with 1 to 2 drops of $10 \% \mathrm{HCl}$ to remove carbonates. Samples were placed on a hot plate to evaporate excess acid. The acidification step was repeated and samples were allowed to dry overnight in a $50^{\circ} \mathrm{C}$ drying oven. Total carbon and nitrogen were measured using a Carlo Erba NA2500 elemental analyzer.

Sediment chlorophyll a: For analysis of sediment microalgal biomass, triplicate sediment samples were collected using $3.98 \mathrm{~cm}^{2}$ core tubes. The 0 to $1 \mathrm{~cm} \mathrm{sec}-$ tion of each core was removed and stored frozen. Analysis was performed according to the protocol of Lorenzen (1967), as modified by Pinckney \& Zingmark (1994) to include extraction of the sediment (unground) with $10 \mathrm{ml}$ of extractant (45\% methanol, $45 \%$ acetone, $10 \%$ deionized water) at $-15^{\circ} \mathrm{C}$ for $72 \mathrm{~h}$.

Metabolism studies. Sediment-water fluxes of dissolved inorganic and organic species were measured in microcosms, which consisted of $8 \mathrm{~cm}$ i.d. $\times 30 \mathrm{~cm}$ tall transparent acrylic core tubes with magnetic stirrers

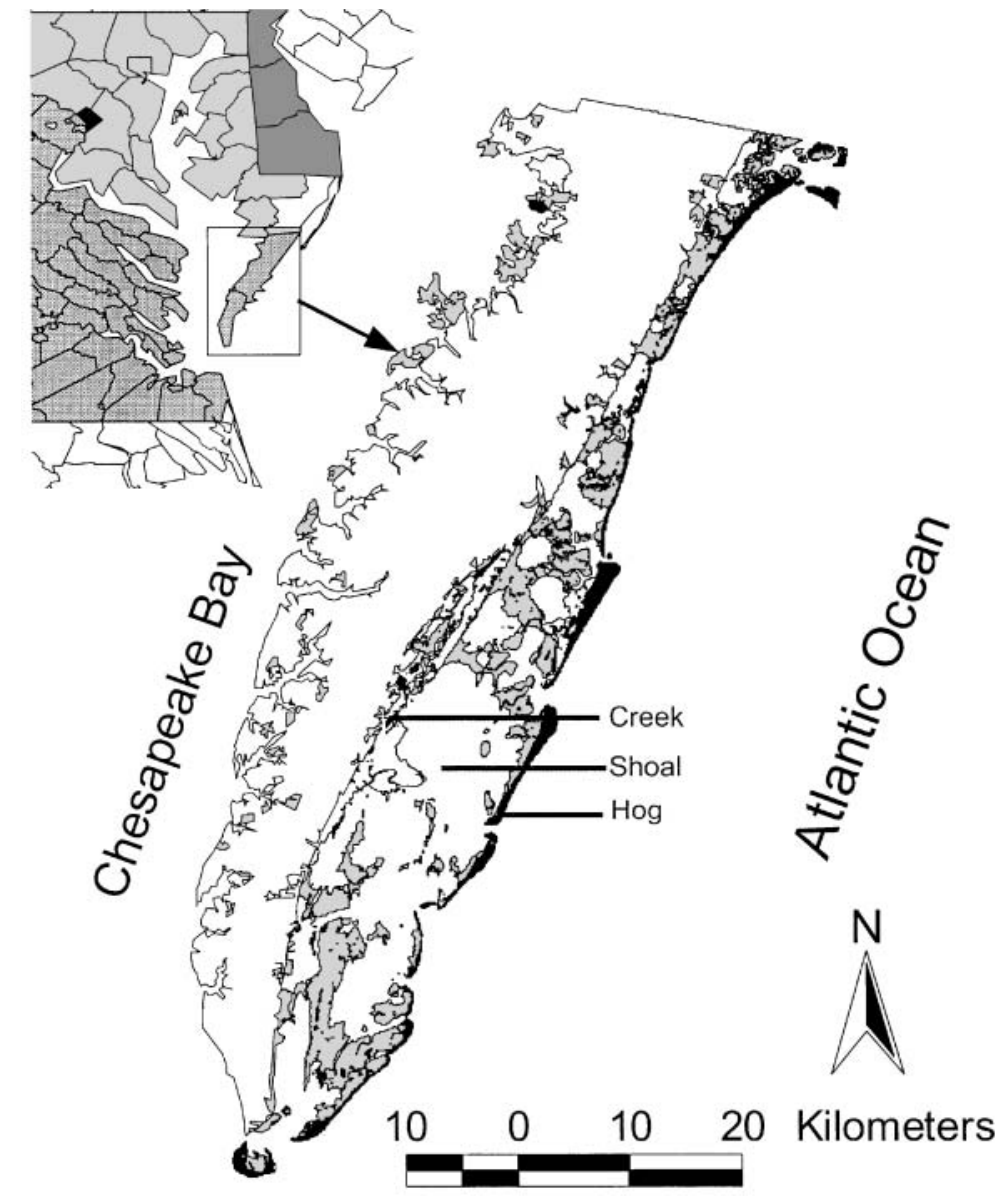

Fig. 1. Map of the Delmarva Peninsula and Hog Island Bay, showing the location of the 3 sampling sites: mainland Creek, mid-lagoon Shoal, and barrier island Hog 
attached to the clear tops that mixed the water column continuously at $60 \mathrm{rpm}$ without disturbing the sediment. Triplicate sets of sediment cores (approximately $12 \mathrm{~cm}$ depth) were collected at each site along with water. Cores were left overnight, uncovered in outdoor, flowing seawater tables to equilibrate. Prior to starting the experiment, water overlying the sediment was replaced with water collected from the same station. Sediment cores along with triplicate sets of water blanks from each station were incubated for $6 \mathrm{~h}$ under ambient light and temperature conditions, followed by $6 \mathrm{~h}$ in the dark. Macroalgae were not included in any of the core incubations. Samples $(30 \mathrm{ml})$ were taken at $2 \mathrm{~h}$ intervals and analyzed for DIN and DON as described below. Sample volumes were replaced with water collected at each of the sampling sites. Sample concentrations were corrected for dilution. Water temperatures and incident photosynthetically active radiation conditions during incubation periods were as follows: May $1998,22^{\circ} \mathrm{C}$, 876-1874 $\mu \mathrm{E} \mathrm{m}^{-2} \mathrm{~s}^{-1}$; July 1998, $26^{\circ} \mathrm{C}, 841-1335 \mu \mathrm{E} \mathrm{m} \mathrm{m}^{-2} \mathrm{~s}^{-1}$; August $1998,30^{\circ} \mathrm{C}$, 329-1433 $\mu \mathrm{E} \mathrm{m}^{-2} \mathrm{~s}^{-1}$; October $1997,17^{\circ} \mathrm{C}, 700-1200 \mu \mathrm{E}$ $\mathrm{m}^{-2} \mathrm{~s}^{-1}$.

Water chemistry. DIN: Ammonium, nitrate, and nitrite were analyzed as described above for sediment extractable nutrients.

Total dissolved nitrogen (TDN): TDN was measured as $\mathrm{NO}_{3}{ }^{-}$following alkaline persulfate digestion (modified from Koroleff 1983). Alkaline persulfate solution (0.5 ml, containing $5 \%$ persulfate, Fisher Certified ACS with a TN content of $0.0005 \%$ in $0.375 \mathrm{M}$ sodium hydroxide and $0.485 \mathrm{M}$ boric acid) was added to $5 \mathrm{ml}$ of sample contained in $10 \mathrm{ml}$ pre-combusted ampoules (Kimball/Kontes). The ampoules were sealed immediately and autoclaved for $1 \mathrm{~h}$. Following digestion TDN was analyzed as $\mathrm{NO}_{3}{ }^{-}$(described above). DON was calculated as the difference between TDN and DIN $\left(\mathrm{NH}_{4}{ }^{+}+\mathrm{NO}_{3}{ }^{-}+\mathrm{NO}_{2}{ }^{-}\right)$.

Chlorophyll a: Chl a was determined as described by Shoaf \& Lium (1976). Five ml water samples were filtered through $25 \mathrm{~mm}$ filters (Whatman GFF) and extracted for $24 \mathrm{~h}$ at room temperature in the dark in $8 \mathrm{ml}$ of a DMSO/acetone mixture (45\% acetone, $45 \%$ DMSO, $10 \%$ deionized water containing $0.1 \%$ diethylamine). Samples were analyzed using a Turner Designs Fluorometer, Model 10-AU. Chl a concentrations were not corrected for degradation products.

Nitrogen cycling processes. Gross N mineralization was determined by ${ }^{15} \mathrm{NH}_{4}{ }^{+}$isotope pool dilution as described in Anderson et al. (1997). Sediment $(10 \mathrm{~cm}$ depth) was collected seasonally from each station using polycarbonate core tubes $(5.7 \mathrm{~cm}$ i.d.) with 4 rows of holes drilled down the length at $0.5 \mathrm{~cm}$ intervals and filled with silicone. Immediately prior to the start of each experiment overlying water was siphoned from each core. Cores were then injected with $4.0 \mathrm{ml}$ (0.1 ml hole $\left.{ }^{-1}\right)$ of argon-sparged water containing $\left({ }^{15} \mathrm{NH}_{4}\right)_{2} \mathrm{SO}_{4}(2 \mathrm{mM}, 99.7$ at.\%) to an approximate final concentration of $200 \mu \mathrm{M}$ and 30 at. $\%{ }^{15} \mathrm{~N}$ enrichment in porewater. After injection, seawater collected from the sampling site was added back to the sediment core. Cores were incubated under ambient temperature conditions in the dark for 0 and $24 \mathrm{~h}$. At 0 and $24 \mathrm{~h}$, 3 cores site $^{-1}$ were sacrificed by removing their overlying water, followed by the addition of $\mathrm{KCl}(255 \mathrm{ml}$, $2 \mathrm{M}$ ). Sediment slurries were shaken in Whirl-pak ${ }^{\circledR}$ bags for $1 \mathrm{~h}$ on a rotary shaker at room temperature and centrifuged. Supernatants were filtered $(0.45 \mu \mathrm{m}$, Gelman Supor Acrodiscs), stored frozen in Whirl-pak ${ }^{\circledR}$ bags until analyzed for $\mathrm{NH}_{4}{ }^{+}, \mathrm{NO}_{3}{ }^{-}$, and $\mathrm{NO}_{2}{ }^{-}$. Remaining supernatants were then transferred to sterile, disposable specimen cups. After addition of magnesium oxide $(\mathrm{MgO}, 0.2 \mathrm{~g}){ }^{15} \mathrm{~N}$-labelled $\mathrm{NH}_{4}{ }^{+}$was trapped on acidified $\left(\mathrm{KHSO}_{4}, 10 \mu \mathrm{l}, 2.5 \mathrm{M}\right.$ ) paper filters (Whatman \#3, $7 \mathrm{~mm}$ ), as described by Brooks et al. (1989). Disks were dried overnight in a dessicator over concentrated sulfuric acid, wrapped in tin capsules, and analyzed for $\mathrm{TN}$ and ${ }^{15} \mathrm{~N}$ enrichment using an elemental analyzer coupled to an isotope ratio mass spectrometer at the University of California at Davis. Rates of mineralization were determined using a model described by Wessel \& Tietema (1992), which takes into account both changes in enrichment of the ${ }^{15} \mathrm{~N}$-labelled pool and the total concentration of that pool $\left({ }^{15} \mathrm{~N}+{ }^{14} \mathrm{~N}\right)$; the model is similar to that derived by Blackburn (1979). Assumptions of the model are as follows: (1) ${ }^{14} \mathrm{~N}$ and ${ }^{15} \mathrm{~N}$ behave (bio-)chemically alike; (2) the pools in which ${ }^{15} \mathrm{~N}$ is measured are homogeneous with respect to consumption and extraction; (3) ${ }^{15} \mathrm{~N}$ abundance of organic $\mathrm{N}$ is at natural abundance; and (4) gross transformation rates remain constant during the incubation period.

Statistical analyses. Differences in fluxes of $\mathrm{NH}_{4}{ }^{+}$, $\mathrm{NO}_{3}{ }^{-}$, and DON and differences in rates of gross mineralization and $\mathrm{NH}_{4}{ }^{+}$consumption were tested using 2-way ANOVA with Station and Season as main factors (StatView, SAS Institute). A post hoc multiple comparisons test (Fisher's protected least significant difference) was then used to perform multiple pair-wise comparisons of means by station or season. Differences were considered to be significant at $\mathrm{p}=0.05$.

\section{RESULTS}

\section{Sediment organic matter and nutrient gradients across HIB}

When averaged over all sampling dates, sediment organic and TN contents differed significantly between all sites, with decreasing values along the tran- 
Table 1. Sediment characteristics across the HIB transect. -: single data point

\begin{tabular}{|c|c|c|c|c|c|c|c|c|c|c|c|}
\hline \multirow[t]{2}{*}{ Sites } & \multirow[t]{2}{*}{ Season } & \multicolumn{2}{|c|}{ Organic content } & \multicolumn{2}{|c|}{ Total nitrogen } & \multicolumn{2}{|c|}{$\mathrm{NH}_{4}^{+}$} & \multicolumn{2}{|c|}{$\mathrm{NO}_{3}^{-}$} & \multicolumn{2}{|c|}{ Chl a } \\
\hline & & $\%$ & $\mathrm{SE}$ & $\mathrm{mol} \mathrm{N} \mathrm{m}{ }^{-2}$ & SE & $\mathrm{mmol} \mathrm{N} \mathrm{m}^{-2}$ & SE & $\mu \mathrm{mol} \mathrm{N} \mathrm{m}^{-2}$ & $\mathrm{SE}$ & $\mathrm{mg} \mathrm{m}^{-2}$ & SE \\
\hline \multirow[t]{3}{*}{ Creek } & May & 3.45 & 0.35 & 20.51 & 2.09 & 1.50 & 0.47 & 4.16 & 2.15 & 18.78 & 2.19 \\
\hline & Aug & 3.40 & - & 25.24 & 0.00 & 0.60 & 0.07 & 16.50 & 1.71 & 11.06 & 2.05 \\
\hline & Oct & 3.35 & 0.36 & 16.96 & 1.80 & 0.56 & 0.09 & 12.90 & 1.31 & 26.50 & 2.84 \\
\hline \multirow[t]{3}{*}{ Shoal } & May & 1.98 & 0.20 & 5.72 & 0.57 & 0.30 & 0.05 & 12.68 & 5.89 & 11.18 & 1.04 \\
\hline & Aug & 2.90 & 1.32 & 6.13 & 0.11 & 1.22 & 0.13 & 11.17 & 1.66 & 17.23 & 1.49 \\
\hline & Oct & 1.72 & 0.09 & 4.20 & 0.23 & 0.72 & 0.04 & 17.39 & 2.26 & 36.11 & 5.86 \\
\hline \multirow[t]{3}{*}{ Hog } & May & 0.67 & 0.11 & 0.23 & 0.04 & 0.24 & 0.06 & 24.48 & 2.09 & 41.59 & 8.23 \\
\hline & Aug & 0.78 & 0.11 & 1.05 & 0.14 & 0.36 & 0.02 & 17.39 & 1.20 & 84.37 & 8.70 \\
\hline & Oct & 1.32 & 0.00 & 1.28 & 0.00 & 0.48 & 0.02 & 58.02 & 7.50 & 30.41 & 1.81 \\
\hline
\end{tabular}

sect across HIB, from the mainland creek to the barrier island. Mean annual values for \% organic content varied from 3.40 (Creek) to 2.20 (Shoal) to 0.92 (Hog). TN $\left(\mathrm{mol} \mathrm{N} \mathrm{m}{ }^{-2}\right.$ ) varied from 20.90 at Creek to 5.35 at Shoal to 0.85 at Hog (Table 1). Seasonally, there was no clear pattern of change in organic matter at Creek and Shoal, although organic content was significantly higher at Hog during October compared with August (seasonal means of 1.32 and $0.78 \%$, respectively). Similarly, there were no significant seasonal differences in sediment TN values, except at Hog, where values were higher in October than in August and May (seasonal means of 1.28, $1.05,0.23 \mathrm{~mol} \mathrm{~N} \mathrm{~m}^{-2}$ respectively). Extractable sediment $\mathrm{NH}_{4}{ }^{+}$was generally higher at Creek and Shoal than at Hog (annual means of 886, 747, $360 \mu \mathrm{mol} \mathrm{N} \mathrm{m}^{-2}$, respectively), although differences were only significant during May. Nitrate concentrations (annual means of 11.19, 13.75, and $33.30 \mu \mathrm{mol} \mathrm{N} \mathrm{m}{ }^{-2}$ at Creek, Shoal, and Hog, respectively), which were at least an order of magnitude lower than $\mathrm{NH}_{4}{ }^{+}$, were typically highest in the sandy sediments of the Hog site, with significantly higher values at Hog than Shoal in August and October and higher than Creek in May and October. Hog sediments also supported higher chl a-containing biomass than did the other sites, except in October (annual means of 18.78, 21.51 and $52.12 \mathrm{mg} \mathrm{m}^{-2}$ at Creek, Shoal, and Hog, respectively).

\section{Water-column characteristics across the HIB transect}

DIN concentrations were highest in October at all sites (Table 2). $\mathrm{NH}_{4}{ }^{+}$was highest at Shoal in July and October and at Hog in May; $\mathrm{NO}_{3}{ }^{-}$was higher at Shoal than at the other sites in October and highest at Creek in July and August. DON concentrations exceeded DIN by approximately an order of magnitude during most seasons. DON averaged for all sites increased steadily from May 1998 through August 1998. Seasonally DON peaked at the Creek site in July, at Shoal in August, and at Hog in July/August. Phytoplankton biomass measured concurrently with our process-level studies (here represented by chl a) was low, with the highest values observed during August.

Table 2. Water-column characteristics. DON: dissolved organic nitrogen; DIP: dissolved in organic phosphorus

\begin{tabular}{|c|c|c|c|c|c|c|c|c|c|c|c|}
\hline \multirow{2}{*}{ Stn } & \multirow{2}{*}{ Season } & \multicolumn{2}{|c|}{ Ammonium } & \multicolumn{2}{|c|}{ Nitrate } & \multicolumn{2}{|c|}{ DON } & \multicolumn{2}{|c|}{ DIP } & \multicolumn{2}{|c|}{ Chl a } \\
\hline & & $\mu \mathrm{M}-\mathrm{N}$ & $\mathrm{SE}$ & $\mu \mathrm{M}-\mathrm{N}$ & $\mathrm{SE}$ & $\mu \mathrm{M}-\mathrm{N}$ & $\mathrm{SE}$ & $\mu \mathrm{M}-\mathrm{P}$ & SE & $\mu g \mathrm{l}^{-1}$ & SE \\
\hline \multirow[t]{4}{*}{ Creek } & May & 0.63 & 0.08 & 0.17 & 0.18 & 15.60 & 0.19 & 0.35 & 0.00 & 2.69 & 0.46 \\
\hline & Jul & 0.87 & 0.03 & 0.78 & 0.01 & 21.38 & 0.04 & nd & & & 0.27 \\
\hline & Aug & 0.73 & 0.16 & 0.56 & 0.02 & 16.36 & 2.29 & 1.05 & 0.01 & 5.75 & \\
\hline & Oct & 2.68 & 0.00 & 2.97 & 0.00 & 11.05 & 0.00 & 1.18 & 0 & 0.60 & \\
\hline \multirow[t]{4}{*}{ Shoal } & May & 0.54 & 0.12 & 0.00 & 0.00 & 11.81 & 0.01 & 0.32 & 0.00 & 2.37 & 0.05 \\
\hline & Jul & 4.94 & 1.1 & 0.00 & 0.00 & 12.57 & 1.10 & nd & & & \\
\hline & Aug & 1.19 & 0.93 & 0.36 & 0.07 & 20.48 & 2.54 & 1.10 & 0.05 & 3.97 & \\
\hline & Oct & 4.72 & 0.00 & 3.46 & 0.05 & 8.22 & 0.05 & 1.30 & 0 & 0.68 & \\
\hline \multirow[t]{4}{*}{ Hog } & May & 1.09 & 0.23 & 0.00 & 0.00 & 11.86 & 0.01 & 0.10 & 0.04 & 1.03 & 0.02 \\
\hline & Jul & 1.00 & 0.04 & 0.51 & 0.06 & 14.11 & 0.07 & nd & & & \\
\hline & Aug & 0.36 & 0.12 & 0.32 & 0.10 & 15.75 & 2.16 & 0.43 & 0.03 & 3.58 & 0.19 \\
\hline & Oct & 2.39 & 0.00 & 2.08 & 0.00 & 11.75 & 0.00 & 0.97 & 0 & 0.88 & \\
\hline
\end{tabular}




\section{Sediment-water fluxes of inorganic and organic $\mathbf{N}$}

All fluxes shown in Figs. 2 to 4 were normalized per $\mathrm{m}^{2}$ of water bottom and integrated over the average watercolumn depth of $1 \mathrm{~m}$ to allow determination of the relative importance of water-column processes within a $\mathrm{m}^{3}$ of water compared to sediment processes affecting an overlying $\mathrm{m}^{3}$ of water. Sediment fluxes were corrected for the effects of water-column processes by subtracting changes in nutrient concentrations observed in water column 'blanks' from those observed in sediment cores. Net daily fluxes were calculated as

$$
F_{\mathrm{T}}=\left(F_{\mathrm{L}} \times t_{\mathrm{L}}\right)+\left(F_{\mathrm{D}} \times t_{\mathrm{D}}\right)
$$

where $F_{\mathrm{T}}$ represents total daily flux, $F_{\mathrm{L}}$ represents flux in the light, $F_{\mathrm{D}}$ represents flux in the dark, and $t$ represent time in $\mathrm{h}$ of light or dark.

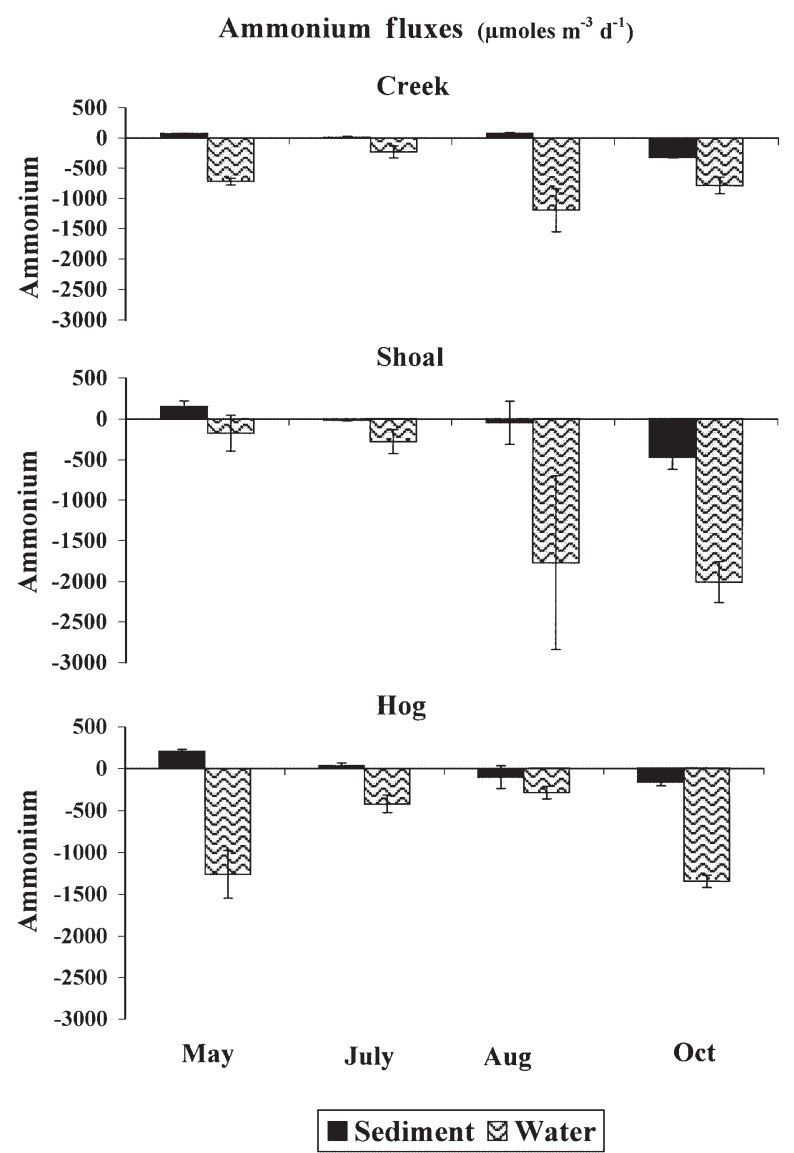

Fig. 2. Sediment-water column fluxes and water-column metabolism of ammonium $\left(\mu \mathrm{mol} \mathrm{m} \mathrm{m}^{-2} \mathrm{~d}^{-1}\right)$ at Creek, Shoal, and Hog stations. Sediment fluxes were corrected by subtraction of water 'blanks'. Error bars represent standard errors for $\mathrm{n}=3$ replicate samples. Units are given as $\mu \mathrm{mol} \mathrm{m}{ }^{-2}$ of bottom for both sediment cores and water-column 'blanks'; however data given for the water column are integrated over an average water column depth of $1 \mathrm{~m}$
When integrated over a $1 \mathrm{~m}$ deep water column, net changes in DIN concentrations were greater in the water-column-only incubations than in the sedimentwater incubations. In the water column metabolism resulted in net uptake of $\mathrm{NH}_{4}{ }^{+}$at all sites and during all seasons (Fig. 2). During May, $\mathrm{NH}_{4}{ }^{+}$immobilization in the water column was significantly higher at Hog than at the other sites, whereas in October highest uptake was observed at the Shoal site. The sediments, on the other hand, were neither a significant net source nor sink of $\mathrm{NH}_{4}{ }^{+}$. Similarly, water-column processes took up $\mathrm{NO}_{3}^{-}$at all sites in August, with a significantly higher uptake at Creek compared to the other sites; however, in October water-column processes were a significant source of $\mathrm{NO}_{3}{ }^{-}$at $\mathrm{Hog}$ (Fig. 3). Sediment fluxes of $\mathrm{NO}_{3}{ }^{-}$were negligible except during October, when there was significant net uptake at all sites.
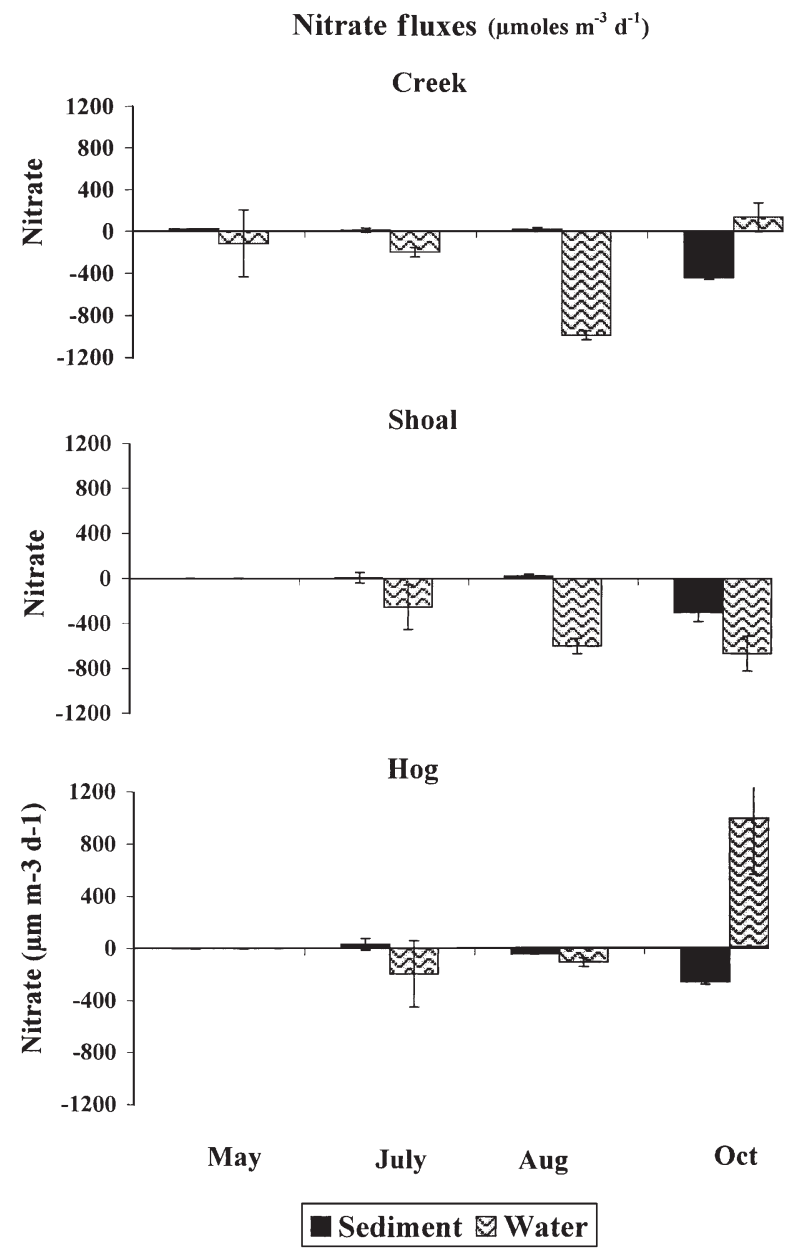

Fig. 3. Sediment-water column fluxes and water-column metabolism of nitrate $\left(\mu \mathrm{mol} \mathrm{m} \mathrm{m}^{-2} \mathrm{~d}^{-1}\right)$ at Creek Shoal, and Hog stations. Sediment fluxes were corrected by subtraction of water 'blanks'. Error bars represent standard errors for $\mathrm{n}=3$ replicate samples 
Table 3. Sediment nitrogen mineralization and turnover

\begin{tabular}{|c|c|c|c|c|c|c|c|}
\hline \multirow[t]{2}{*}{ Stn } & \multirow[t]{2}{*}{ Season } & \multicolumn{2}{|c|}{ Mineralization rate } & \multicolumn{2}{|c|}{ Consumption rate } & \multirow{2}{*}{$\begin{array}{l}\mathrm{NH}_{4}^{+} \text {turnover } \\
\text { time (d) }\end{array}$} & \multirow{2}{*}{$\begin{array}{l}\text { TN turnover } \\
\text { time (d) }\end{array}$} \\
\hline & & $\mathrm{mmol} \mathrm{N} \mathrm{m}{ }^{-2} \mathrm{~d}^{-1}$ & $\mathrm{SE}$ & $\mathrm{mmol} \mathrm{N} \mathrm{m} \mathrm{m}^{-2} \mathrm{~d}^{-1}$ & $\mathrm{SE}$ & & \\
\hline \multirow[t]{3}{*}{ Creek } & May & 5.20 & 0.90 & 4.02 & 0.96 & 0.29 & 3.95 \\
\hline & Aug & 3.50 & 0.87 & 2.27 & 0.71 & 0.17 & 7.22 \\
\hline & Oct & 3.97 & 0.60 & 4.27 & 0.55 & 0.14 & 4.27 \\
\hline \multirow[t]{3}{*}{ Shoal } & May & 6.53 & 1.13 & 4.57 & 1.45 & 0.05 & 0.88 \\
\hline & Aug & 3.24 & 0.60 & 3.97 & 0.70 & 0.38 & 1.89 \\
\hline & Oct & 0.93 & 1.77 & 2.76 & 2.82 & 0.78 & 4.53 \\
\hline \multirow[t]{3}{*}{ Hog } & May & 3.50 & 1.56 & 8.76 & 2.98 & 0.07 & 0.07 \\
\hline & Aug & 4.74 & 0.82 & 2.41 & 0.53 & 0.08 & 0.22 \\
\hline & Oct & 2.06 & 0.86 & 1.68 & 0.27 & 0.23 & 0.62 \\
\hline
\end{tabular}

Water-column processes released either negligible or zero amounts of DON in May and took up DON during July at Creek and Shoal (Fig. 4). By August there was net release of DON at the Creek station, continued uptake at Shoal, and at Hog fluxes were not significantly different from zero. Then in October watercolumn processes resulted in net release of DON at all sites. Sediments at all sites released DON to the water column during August, whereas during October fluxes were either negligible (Shoal and Creek) or there was net uptake (Hog). The magnitude of the DON fluxes tended to be far greater than those of $\mathrm{NH}_{4}{ }^{+}$or $\mathrm{NO}_{3}{ }^{-}$.

\section{Sediment nitrogen mineralization, $\mathrm{NH}_{4}{ }^{+}$ consumption, and turnover}

In order to determine the role that sediment processes play in affecting $\mathrm{N}$ exchanges between the water column and sediments, we measured sediment gross $\mathrm{NH}_{4}{ }^{+}$production and consumption. Note that all sediment process rates are given in units of $\mathrm{mmol} \mathrm{N} \mathrm{m}^{-2}$ $\mathrm{d}^{-1}$ (Tables 3 to 5 ) whereas flux rates, which were much lower, are given in units of $\mu \mathrm{mol} \mathrm{N} \mathrm{m} \mathrm{N}^{-2} \mathrm{~d}^{-1}$ (Figs. 2 to 4 ). Results shown in Table 3 suggest that the sediment $\mathrm{NH}_{4}{ }^{+}$pool turned over on time scales of $<1 \mathrm{~d}$; however, as rapidly as $\mathrm{NH}_{4}{ }^{+}$was produced by mineralization, it was consumed either by benthic microalgal or bacterial uptake or by nitrification. Between May and October the sediment TN pool turnover time ranged from 0.07 to $7.2 \mathrm{~d}$, with highest turnover in those sediments with lowest organic content (Hog site) (Table 3). Significant differences in gross mineralization rates were observed between seasons but not between stations.

\section{Measured versus calculated molar $\mathrm{C} / \mathrm{N}$ ratios}

The molar $\mathrm{C} / \mathrm{N}$ ratios of the products of bacterial mineralization of organic matter (OM) were compared to the molar $\mathrm{C} / \mathrm{N}$ of sediments and macroalgae collected from each site (Table 4). Although live macroalgae were not included in the incubations reported here, detrital material derived from decaying spring/ summer macroalgal blooms or from buried macroalgae was likely present within the sediments. Mineralized

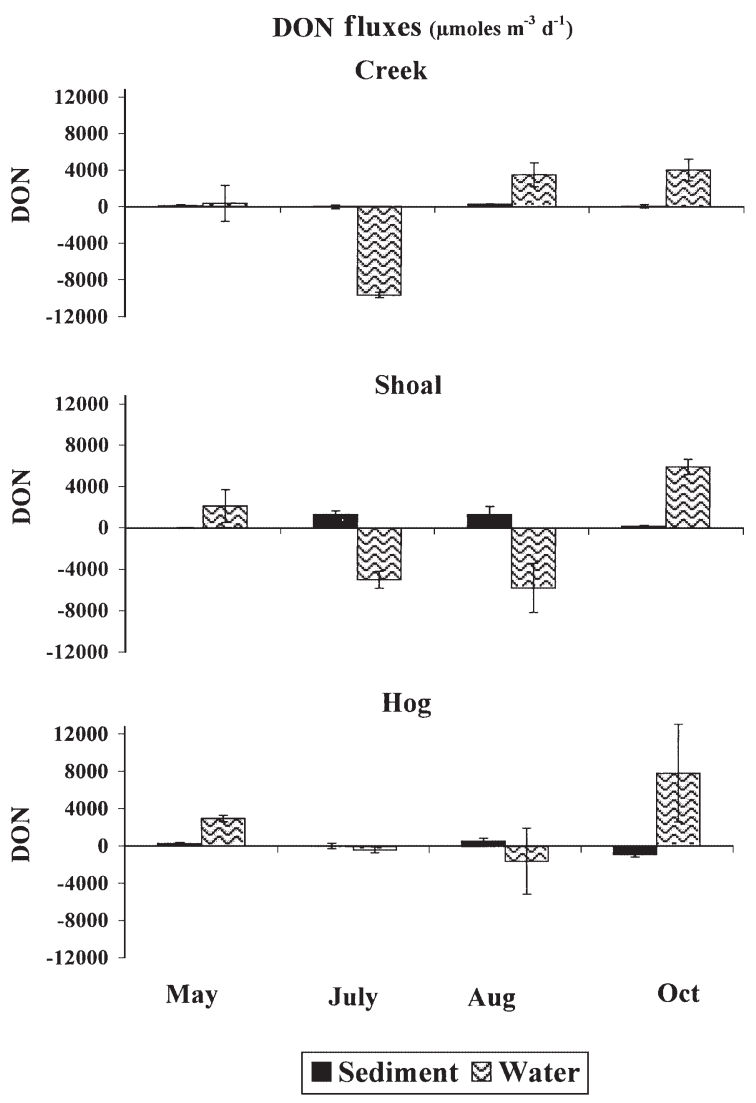

Fig. 4. Sediment-water column fluxes and water-column metabolism of DON $\left(\mu \mathrm{mol} \mathrm{m} \mathrm{m}^{-2} \mathrm{~d}^{-1}\right)$ at Creek, Shoal, and Hog stations. Sediment fluxes were corrected by subtraction of water 'blanks'. Error bars represent standard errors for $n=3$ replicate samples 
Table 4. Calculated molar $\mathrm{C} / \mathrm{N}$ of mineralized sediment organic matter

\begin{tabular}{|c|c|c|c|c|c|c|}
\hline Stn & Season & $\begin{array}{l}\text { Bacterial respiration } \\
\left(\mathrm{mmol} \mathrm{C} \mathrm{m}^{-2} \mathrm{~d}^{-1}\right)^{\mathrm{a}}\end{array}$ & $\begin{array}{l}\text { Nitrogen mineralization } \\
\quad\left(\mathrm{mmol} \mathrm{N} \mathrm{m} \mathrm{m}^{-2} \mathrm{~d}^{-1}\right)^{\mathrm{b}}\end{array}$ & $\mathrm{C} / \mathrm{N}$ mineralized ${ }^{\mathrm{c}}$ & $\begin{array}{l}\text { Sediment } \mathrm{C} / \mathrm{N} \\
-(\text { molar }) \\
\end{array}$ & Macroalgal C/N \\
\hline \multirow[t]{3}{*}{ Creek } & May & 82.97 & 5.20 & 15.97 & 11.30 & 20.30 \\
\hline & Aug & 0.00 & 3.50 & 0.00 & 19.10 & 17.80 \\
\hline & Oct & 62.83 & 3.97 & 15.83 & 12.30 & 10.10 \\
\hline \multirow[t]{3}{*}{ Shoal } & May & 50.40 & 6.53 & 7.72 & 12.20 & 19.60 \\
\hline & Aug & 0.00 & 3.24 & 0.00 & 8.20 & 17.70 \\
\hline & Oct & 109.22 & 0.93 & 117.44 & 14.80 & 13.30 \\
\hline \multirow[t]{3}{*}{ Hog } & May & 23.52 & 3.50 & 6.72 & 21.70 & 44.70 \\
\hline & Aug & 17.58 & 4.74 & 3.71 & 2.80 & 33.60 \\
\hline & Oct & 0.00 & 2.06 & 0.00 & 17.00 & 18.40 \\
\hline \multicolumn{7}{|c|}{$\begin{array}{l}\text { a Based upon net sediment DIC flux in the dark after subtraction of microalgal respiration, assumed to equal to } 0.1 \mathrm{GPP} \text {, as in } \\
\text { Cloern (1987). DIC fluxes, measured concurrent with this study are reported in McGlathery et al. (2001) } \\
\text { b Measured as gross N mineralization by the isotope pool dilution technique } \\
{ }^{\mathrm{c}} \text { The molar ratio of bacterial C respired to gross N mineralized }\end{array}$} \\
\hline
\end{tabular}

$\mathrm{C} / \mathrm{N}$ ratios were calculated based upon measured gross $\mathrm{N}$ mineralization rates as well as measured sediment community respiration rates (sediment-water dark DIC fluxes), corrected for microalgal respiration assuming that benthic microalgal respiration equaled $10 \%$ of gross sediment primary production, as discussed in Cloern (1987). Calculated molar C/N ratios of mineralized OM were highly variable, ranging from close to zero, when we were unable to detect bacterial respiration (August at the Shoal site and October at the Hog site), to 126 in October at the Shoal site, when bacterial respiration rates were very high but $\mathrm{N}$ mineralization rates were very low. These data suggest large seasonal and spatial variations in the sources of DOM undergoing both respiration and mineralization in HIB.

\section{Production versus consumption of $\mathrm{NH}_{4}{ }^{+}$in $\mathrm{HIB}$ sediments}

The $\mathrm{NH}_{4}{ }^{+}$produced by gross mineralization was rapidly consumed by sediments in the dark. Processes potentially responsible for consumption include nitrification, bacterial immobilization, and dark uptake by benthic microalgae (Table 5). Based upon daily DIN fluxes, measured in both light and dark, and $\mathrm{NH}_{4}{ }^{+}$ production and consumption rates determined in isotope dilution studies conducted only in the dark, we calculated potential rates of nitrification and denitrification. These calculations assumed that microalgal uptake of $\mathrm{N}$ was not important in the dark, an assumption that is likely to be false and that requires further verification. For comparison, we also calculated benthic microalgal $\mathrm{N}$ demand based upon gross primary production (GPP), corrected for autotrophic respiration $\left(R_{\mathrm{a}}\right) . R_{\mathrm{a}}$ was assumed to equal $10 \%$ of GPP, according to the discussion of Cloern (1987). A molar $\mathrm{C} / \mathrm{N}$ ratio of 9, as reported by Sundback et al. (2000) was used to convert carbon fixed to $\mathrm{N}$ demand by benthic microalgae.

Potential $\mathrm{NH}_{4}{ }^{+}$uptake by nitrification was estimated by subtracting measured sediment-water $\mathrm{NH}_{4}{ }^{+}$fluxes (both positive and negative) from measured gross mineralization rates (Fig. 2, Tables 3 \& 5). Potential nitrification rates thus calculated were similar to $\mathrm{NH}_{4}{ }^{+}$consumption rates measured by isotope pool dilution (Table 5). Potential denitrification rates were similarly calculated by subtracting measured $\mathrm{NO}_{3}{ }^{-}$fluxes from calculated nitrification rates. Calculation of potential denitrification assumed that dark uptake of $\mathrm{NO}_{3}{ }^{-}$by benthic microalgae and dissimilatory reduction to $\mathrm{NH}_{4}{ }^{+}$were negligible relative to denitrification (Fig. 3, Table 5).

Our estimates of benthic microalgal nitrogen demand exceeded rates of $\mathrm{NH}_{4}{ }^{+}$production by gross mineralization at all stations and during all seasons (Tables 3 \& 5). However, we recognize that our calculations of benthic microalgal $\mathrm{N}$ demand, which are based on GPP, likely overestimate dark $\mathrm{N}$ demand. In addition, we did not take into account losses of DOC and DON, which would in effect further reduce the $\mathrm{N}$ demand.

\section{DISCUSSION}

Whereas rivers are the primary source of 'reactive' $\mathrm{N}$ to estuarine systems, groundwater in the shallow aquifer is likely the major source of $\mathrm{N}$ to coastal lagoons such as HIB (Valiela et al. 1992, Nowicki et al. 1999). The influence of nutrients derived from the mainland in HIB is apparent in the gradient of both organic content and TN found in sediments along the 
Table 5. Mechanisms potentially responsible for sediment $\mathrm{N}$ consumption

\begin{tabular}{|c|c|c|c|c|}
\hline $\begin{array}{l}\text { Stn } \\
\quad \text { Season }\end{array}$ & $\begin{array}{l}\text { Measured } \\
\text { consumption }^{\mathrm{a}}\end{array}$ & $\begin{array}{c}\text { Potential } \\
\text { nitrification }^{\mathrm{b}}\end{array}$ & $\begin{array}{l}\text { Potential denitrification }{ }^{\mathrm{c}} \\
\qquad\left(\mathrm{mmol} \mathrm{N} \mathrm{m}^{-2} \mathrm{~d}^{-1}\right)\end{array}$ & $\begin{array}{c}\text { Calculated microalgal } \\
\mathrm{N} \mathrm{demand}^{\mathrm{d}}\end{array}$ \\
\hline \multicolumn{5}{|l|}{ Creek } \\
\hline May & 4.02 & 5.17 & 5.16 & 10.86 \\
\hline Aug & 2.27 & 3.50 & 3.56 & 7.43 \\
\hline Oct & 4.27 & 4.35 & 4.79 & 7.49 \\
\hline \multicolumn{5}{|l|}{ Shoal } \\
\hline May & 4.57 & 6.40 & 6.40 & 8.16 \\
\hline Aug & 3.97 & 3.40 & 3.42 & 10.18 \\
\hline Oct & 2.76 & 1.53 & 1.88 & 16.11 \\
\hline \multicolumn{5}{|l|}{ Hog } \\
\hline May & 8.76 & 3.38 & 3.38 & 4.08 \\
\hline Aug & 2.41 & 4.87 & 4.92 & 10.98 \\
\hline Oct & 1.68 & 2.32 & 2.52 & 2.51 \\
\hline \multicolumn{5}{|c|}{$\begin{array}{l}{ }^{a} \text { Measured using the isotope pool dilution technique } \\
\text { b Estimated based upon the difference between the daily gross } \mathrm{N} \text { mineralization and ammonium flux rates } \\
\text { cEstimated based on the difference between the calculated daily nitrification rate and the measured nitrate flux } \\
\text { d Based on GPP calculated from DIC fluxes with a correction for microalgal respiration (0.1GPP) and a C/N ratio for benthic } \\
\text { microalgae of 9. DIC fluxes, measured concurrent with this study, are reported in McGlathery et al. (2001) }\end{array}$} \\
\hline
\end{tabular}

transect from the mainland to the barrier island (Table 1). In HIB, groundwater inputs are highest in late winter and early spring (Neikirk 1996), concurrent with the rapid increase in macroalgal biomass that peaks during June in the lagoon (McGlathery et al. 2001). Macroalgae serve as a temporary trap for $\mathrm{N}$ in HIB, since in mid-summer when water temperatures peak, macroalgae die off releasing both DON and DIN (Tyler et al. 2001).

In HIB dystrophic events occur occasionally in localized patches within the lagoon, especially the midlagoon shoal area. At a mid-lagoon location, approximately $2 \mathrm{~km}$ from our Shoal site, a massive algal bloom (patches up to $650 \mathrm{gdw} \mathrm{m}^{-2}$ ) crashed in early July 1998. During this period releases of DON from decomposing macroalgae to the water column were on the order of 39 ( $\mathrm{SE}=14) \mathrm{mmol} \mathrm{N} \mathrm{m}^{-2} \mathrm{~d}^{-1}$ and those of DIN 33 ( $\mathrm{SE}=$ 24) mmol N m $\mathrm{N}^{-2} \mathrm{~d}^{-1}$. Tyler et al. (2001) reported that at this efflux rate all of the $\mathrm{N}$ present in macroalgae during the bloom would be mineralized and released within approximately $13 \mathrm{~d}$. Both immediately following collapse of the macroalgal bloom (July study, Tyler et al. 2001), and 5 wk later (August study) we observed increased uptake of DON from the water column, especially at the Shoal site, suggesting either increased lability of the DON to bacterial decomposition or uptake by phytoplankton (Fig. 4). Increased lability may reflect the availability of fresh detrital material derived from macroalgal blooms within the lagoon, or increased uptake may correspond to the higher phytoplankton abundance in the lagoon in mid- to late summer (McGlathery et al. 2001). Rates of DON disappearance from the water column were in the same range as those reported by Bronk \& Glibert (1993) and by Seitzinger \& Sanders (1997). Bronk \& Glibert suggested that in their study phytoplankton were responsible for uptake, whereas Seitzinger \& Sanders determined that bacteria were responsible, since they excluded phytoplankton from their incubations by filtration.

Dystrophic events similar to that which occurred during July 1998 at the mid-lagoon shoal site appear to be relatively rare and localized in HIB. However, Tyler et al. (2001) noted that the presence of macroalgae increased benthic fluxes of DON with an average observed for all sites and seasons of $331 \mu \mathrm{mol} \mathrm{m} \mathrm{m}^{-2} \mathrm{~d}^{-1}$ the average flux of DON from sediments alone (observed in this study) was $198 \mu \mathrm{mol} \mathrm{m} \mathrm{m}^{-2} \mathrm{~d}^{-1}$ (SE = 147). It is interesting to note that in HIB the largest component of the TDN flux was DON, as compared to Burdige \& Zheng's (1998) observations in Chesapeake Bay, where benthic DON fluxes were a small fraction ( 2 to $3 \%$ ) of the TDN flux.

Turnover of the $\mathrm{NH}_{4}{ }^{+}$pool, measured by the isotope pool technique, can result from both gross mineralization of sediment organic matter or from dissimilatory nitrate reduction to $\mathrm{NH}_{4}{ }^{+}$(DNRA). Based on observed sediment concentrations of $\mathrm{NO}_{3}{ }^{-}$versus $\mathrm{NH}_{4}{ }^{+}$(Table 1) and the relatively low $\mathrm{NO}_{3}{ }^{-}$uptake rates by sediments, we assumed in this study that mineralization was the primary process responsible for $\mathrm{NH}_{4}^{+}$production. Gross sediment mineralization rates measured in this study (Table 3) were well within the range for a variety of unvegetated and vegetated coastal sediments given by Herbert (1999). Interestingly, although the sediments along the transect from mainland to barrier 
island displayed a gradient of organic matter and TN content in response to the influence of nutrient export from the mainland, no such gradient in nutrient fluxes or gross mineralization was observed. This suggests that physical factors such as DO, sediment type, and availability of fresh detrital material may have played a more important role in determining the processing of $\mathrm{N}$ in sediments and water column, whereas the TN stored in sediments may have represented refractory material.

With high rates of gross $\mathrm{N}$ mineralization, one would typically expect $\mathrm{NH}_{4}{ }^{+}$release from sediments and a concomitant increase in water-column $\mathrm{NH}_{4}{ }^{+}$as has been observed in flux studies performed in many other systems (Rizzo 1990, Bartoli et al. 1996, Giblin et al. 1997, Burdige \& Zheng 1998, Hopkinson et al. 1999). On the contrary, either net $\mathrm{NH}_{4}{ }^{+}$fluxes from HIB sediments were for the most part not significantly different from zero or there was a net uptake from the water column to sediments. In addition, when integrated over a $1 \mathrm{~m}$ deep water column, uptake of both $\mathrm{NH}_{4}{ }^{+}$and $\mathrm{NO}_{3}{ }^{-}$, measured in water 'blanks' during most seasons, generally exceeded sediment uptake, suggesting $\mathrm{N}$ immobilization either by phytoplankton or bacteria (Figs. 2 \& 3). Watercolumn DIN uptake, normalized to chl a abundance ranged from 0.07 to $2.96 \mu \mathrm{mol} \mathrm{N}(\mu \mathrm{g} \mathrm{chl} \mathrm{a})^{-1}$ for the Shoal site and 0.21 to $1.32 \mu \mathrm{mol} \mathrm{N}(\mu \mathrm{g} \mathrm{chl} \mathrm{a})^{-1}$ for the Creek site. These values are similar to those (1.10 to $4.25 \mu \mathrm{mol} \mathrm{N}[\mu \mathrm{g} \mathrm{chl} \mathrm{a}]^{-1}$ ) observed by Bronk et al. (1998) for the mesohaline Chesapeake Bay region. On the other hand, when filtered HIB water $(1 \mu \mathrm{m})$ was incubated in the dark, it was a net source of $\mathrm{NH}_{4}{ }^{+}$due to metabolism of approximately $0.2 \mathrm{mmol}$ DON-N m${ }^{-2} d^{-1}$ (T. Lunsford pers. comm.). These results suggest that phytoplankton and not bacteria were responsible for the uptake of TDN observed in water-column incubations.

The question thus remains: what is the fate of the $\mathrm{NH}_{4}{ }^{+}$released by mineralization of organic $\mathrm{N}$ in the sediments? Nitrogen consumption rates based upon isotope pool dilution assays in sediment cores (Table 3) were similar in magnitude to measured gross $\mathrm{N}$ mineralization rates. In an attempt to reduce uptake by benthic microalgae, incubations for determinations of mineralization and consumption were performed in the dark. However, it has been reported that microalgae theoretically are capable of $\mathrm{N}$ uptake in the dark (Turpin 1991), although we assume at a reduced rate. Thus, we cannot at this time exclude benthic microalgae as a $\mathrm{N}$ sink competing with nitrifiers for $\mathrm{NH}_{4}{ }^{+}$ mineralized in the dark.

At all sites and during all seasons benthic microalgal $\mathrm{N}$ demand exceeded sediment gross $\mathrm{N}$ mineralization (Tables $3 \& 5$ ). It is likely, however, that our calcula- tions of benthic microalgal $\mathrm{N}$ demand overestimate dark $\mathrm{N}$ uptake, since they are based on GPP and they do not take into account exudation of fixed carbon as DOC. Middleburg et al. (2000) estimate that as much as 42 to $73 \%$ of carbon fixed by benthic diatoms may subsequently be released as DOC. In addition, since light has been shown to enhance oxygen respiration in both microbial mats and in intertidal sediments (Epping \& Jørgensen 1996), it is possible that incubations in the dark caused us to underestimate daily mineralization rates and thus the $\mathrm{N}$ available to support the various processes responsible for uptake.

Another biological process potentially responsible for uptake of $\mathrm{NH}_{4}^{+}$is immobilization by sediment bacteria. Rivera-Monroy \& Twilley (1996) observed high rates of N-immobilization but low rates of coupled nitrification-denitrification in mangrove sediments amended with ${ }^{15} \mathrm{~N}_{-} \mathrm{NH}_{4}{ }^{+}$. They attributed this to the high $\mathrm{C} / \mathrm{N}$ ratio (ranging from 12.9 to 33.2) of decomposing mangrove litter present in the sediments. In the present study, the average $\mathrm{C} / \mathrm{N}$ was $13.3(\mathrm{SE}=1.9)$ for sediment, ranging from 2.8 to 21.7 , and 21.7 ( $\mathrm{SE}=3.6$ ) for macroalgae, ranging from 10.1 to 44.7 , suggesting that in sediments with labile macroalgal detritus some $\mathrm{N}$ immobilization was necessary to support decomposition (Table 4).

It is not possible with our present data set to determine the fate of $\mathrm{NH}_{4}{ }^{+}$produced by gross mineralization. Calculated rates of nitrification and denitrification were similar to estimated benthic microalgal $\mathrm{N}$ demand if we take into account potential carbon exudation. Nowicki et al. (1999) measured denitrification in Nauset Marsh Estuary, Cape Cod (MA), in shallow embayments similar in many respects to our sandy barrier island sites in HIB. Denitrification rates ranged from 0.05 to $0.50 \mathrm{mmol} \mathrm{N} \mathrm{m}^{-2} \mathrm{~d}^{-1}$ and were much lower than estimates in this study. Rysgaard et al. (1996) measured coupled nitrification-denitrification and nitrate ammonification in Etang du Prevost, a coastal lagoon in southern France, a site which like HIB supports a high abundance of both macroalgae and benthic microalgae. In June approximately $22 \%$ of the $\mathrm{NH}_{4}{ }^{+}$produced by mineralization was nitrified and $27 \%$ of the $\mathrm{NO}_{3}{ }^{-}$thus formed was then denitrified. In September following a dystrophic event, nitrification rates were inhibited both by sulfide and sediment anoxia; mineralized $\mathrm{NH}_{4}{ }^{+}$was released to the overlying water. In January the sediment was net autotrophic and benthic microalgae consumed most of the available DIN. Thus, in the Etang du Prevost partitioning of mineralized $\mathrm{NH}_{4}{ }^{+}$showed strong seasonal variation depending upon sediment and water chemistry and benthic microalgal activity.

Herbert (1999) reported nitrification and denitrification rates for a variety of coastal marine and estuarine 
sediments. The mean nitrification rate for 11 sites was 2.7 ( $\mathrm{SE}=0.69) \mathrm{mmol} \mathrm{N} \mathrm{m} \mathrm{N}^{-2} \mathrm{~d}^{-1}$. Reported denitrification rates (measured as $\mathrm{N}_{2}$ flux, ${ }^{15} \mathrm{~N}_{2}$ flux, or by isotope pairing) varied widely for sites such as Narragansett Bay (RI) (3.6 to $47 \mathrm{mmol} \mathrm{N} \mathrm{m}^{-2} \mathrm{~d}^{-1}$ ), Patuxent River Estuary (18-21 $\mathrm{mmol} \mathrm{m}^{-2} \mathrm{~d}^{-1}$ ), and Etang du Prevost (0.07 to $10.9 \mathrm{mmol} \mathrm{N} \mathrm{m}^{-2} \mathrm{~d}^{-1}$ ). Calculated rates (1.99 to $6.40 \mathrm{mmol} \mathrm{N} \mathrm{m}^{-2} \mathrm{~d}^{-1}$ ) in this study fall within the range of these reported rates.

It has been reported that benthic microalgae may out-compete nitrifiers or denitrifiers for substrates (Rysgaard et al. 1996); thus, in littoral zone systems which support an abundant benthic microalgal community, denitrification may not be an important process for removal of $\mathrm{N}$. On the other hand, An \& Joye (2001) observed enhanced rates of coupled nitrification-denitrification in response to $\mathrm{O}_{2}$ or possibly DOC production by benthic microalgae. They observed denitrification rates that were higher during daytime (1.4-3.7 $\mathrm{mmol} \mathrm{m}^{-2} \mathrm{~d}^{-1}$ ) than nighttime (0.1-0.24 mmol $\mathrm{m}^{-2} \mathrm{~d}^{-1}$ ) and suggested that benthic microalgae are likely to out-compete nitrifiers-denitrifiers only when microalgal $\mathrm{N}$ demand exceeds rates of $\mathrm{N}$ regeneration. In HIB, where benthic microalgal $\mathrm{N}$ demand appears to be greater than mineralization rates, we might expect that benthic microalgae are the major sink for mineralized $\mathrm{NH}_{4}{ }^{+}$.

\section{Objectives of future work in HIB}

At this point we are unable to estimate the partitioning of the $\mathrm{N}$ mineralized in HIB sediments between the various potential consumptive processes: immobilization, benthic microalgal uptake, and coupled nitrification-denitrification. However, it is clear that all of these processes are likely to retard and/or remove $\mathrm{N}$ during its transport from the mainland to the coastal ocean. The overall importance of these removal mechanisms will depend upon residence time within the lagoon and rates of advection of water masses through the lagoon relative to biological process rates. We are currently involved in a study to distinguish the relative importance of these consumptive processes in the lagoon by direct and more frequent measurements over an annual cycle. An objective of future work will be the development of a transport model which can relate biological process rates to physical transport.

Acknowledgements. We thank the staff of both Virginia Institute of Marine Science Eastern Shore Laboratory and the University of Virginia VCR-LTER for assistance in the field. We could not have accomplished this work without the able assistance of Betty Neikirk, P. G. Ross, Jessica Burton, Krissy Russell, Alan Moore, and Eva Bailey. This work was supported by
USDA-NRICGP (grand \#2001-35101-09873) and the Virginia Coast Reserve LTER Project (NSF \#DEB-9411974). VIMS contribution number 2512

\section{LITERATURE CITED}

An S, Joye SB (2001) Enhancement of coupled nitrificationdenitrification by benthic photosynthesis in shallow estuarine sediments. Limnol Oceanogr 46(1):62-74

Anderson IC, Tobias CR, Neikirk BB, Wetzel RL (1997) Development of a process-based mass balance model for a Virginia Spartina alterniflora salt marsh. Mar Ecol Prog Ser 159:13-27

Bartoli M, Cattadori M, Giordani G, Viaroli P (1996) Benthic oxygen respiration, ammonium and phosphorus regeneration in surficial sediments of the Sacca di Goro (Northern Italy) and two French coastal lagoons: a comparative study. Hydrobiologia 329:143-159

Blackburn TH (1979) Method for measuring rates of $\mathrm{NH}_{4}^{+}$ turnover in anoxic marine sediments, using a ${ }^{15} \mathrm{~N}_{-} \mathrm{NH}_{4}{ }^{+}$ dilution technique. Appl Environ Microbiol 37:760-765

Bohlke JK, Denver JM (1995) Combined use of groundwater dating, chemical, and isotopic analyses to resolve the history and fate of nitrate contamination in two agricultural watersheds, Atlantic coastal plain, Maryland. Water Resour Res 31:2319-2339

Boynton WR (1996) A comparative analysis of eutrophication patterns in a temperate coastal lagoon. Estuaries 19(2B): $408-421$

Bronk DA, Glibert PM (1993) Application of a ${ }^{15} \mathrm{~N}$ tracer method to the study of dissolved organic nitrogen uptake during spring and summer in Chesapeake Bay. Mar Biol 115:501-508

Bronk DA, Glibert PM, Malone TC, Banahan S, Sahlsten E (1998) Inorganic and organic nitrogen cycling in Chesapeake Bay: autotrophic versus heterotrophic processes and relationships to carbon flux. Aquat Microb Ecol 15: 177-189

Brooks PD, Stark JM, McInteer BB, Preston T (1989) Diffusion method to prepare soil extracts for automated nitrogen-15 analysis. Soil Sci Soc Am Proc 53:1707-1711

Burdige DJ, Zheng S (1998) The biogeochemical cycling of dissolved organic nitrogen in estuarine sediments. Limnol Oceanogr 43(8):1796-1813

Cloern JE (1987) Turbidity as a control on phytoplankton biomass and productivity in estuaries. Cont Shelf Res $7(11 / 12): 1367-1381$

Duarte C (1995) Submerged aquatic vegetation in relation to different nutrient regimes. Ophelia 41:87-112

Epping EHG, Jørgensen BB (1996) Light-enhanced oxygen respiration in benthic phototrophic communities. Mar Ecol Prog Ser 139:193-203

Giblin AE, Gaines AG (1990) Nitrogen inputs to a marine embayment: the importance of groundwater. Biogeochemistry 10:309-328

Giblin AE, Hopkinson CS, Tucker J (1997) Benthic metabolism and nutrient cycling in Boston Harbor, Massachusetts. Estuaries 20(2):346-364

Hamilton PA, Helsel DR (1995) Effects of agriculture on ground-water quality in five regions of the United States. Ground Water 33:217-225

Herbert RA (1999) Nitrogen cycling in coastal marine ecosystems. FEMS Microbiol Rev 23:563-590

Hopkinson CS, Giblin AE, Tucker J, Garritt RH (1999) Benthic metabolism and nutrient cycling along an estuarine salinity gradient. Estuaries 22(4):863-881 
Koroleff F (1983) Total and organic nitrogen. In: Grasshoff K, Ehrhardt M, Kremling K (eds) Methods of seawater analysis. Verlag-Chemie, Weinheim, p 162-169

Lorenzen C (1967) Determination of chlorophyll and phaeopigments: spectrophotometric equations. Limnol Oceanogr 12:343-346

McGlathery KJ, Anderson IC, Tyler AC (2001) Magnitude and variability of benthic and pelagic metabolism in a temperate coastal lagoon. Mar Ecol Prog Ser 216:1-15

Middelburg JJ, Barranguet C, Boschker HTS, Herman, PMJ, Moens T, Heip CHR (2000) The fate of intertidal microhytobenthos carbon: an in situ ${ }^{13} \mathrm{C}$-labeling study. Limnol Oceanogr 45(6):1224-1234

Neikirk BB (1996) Exchanges of dissolved inorganic nitrogen and dissolved organic carbon between salt marsh sediments and overlying water. MS College of William and Mary, Gloucester Point, VA

Nixon SW (1982) Nutrient dynamics, primary production and fisheries yields of lagoons. Oceanol Acta 5(4):357-371

Nowicki BL, Requintina E, Keuren DV, Portnoy J (1999) The role of sediment denitrification in reducing groundwaterderived nitrate inputs to Nauset Marsh estuary, Cape Cod, Massachusetts. Estuaries 22(2A):245-259

Perstorp (1992) Nitrate + nitrite in seawater. Alpkem Corporation, a Perstorp Analytical Company, Wilsonville, OR

Pinckney JL, Zingmark RG (1994) Comparison of highperformance liquid chromatographic, spectrophotometric, and fluorometric methods for determining chlorophyll a concentrations in estuarine sediments. J Microbiol Methods 19:59-66

Reay WG, Gallager DL, Simmons GM (1992) Groundwater discharge and its impact on surface water quality in a Chesapeake Bay inlet. Water Resour Bull 28:1121-1133

Rivera-Monroy VH, Twilley RR (1996) The relative role of denitrification and immobilization in the fate of inorganic nitrogen in mangrove sediments. Limnol Oceanogr 41(2): 284-296

Rizzo WM (1990) Nutrient exchanges between the water column and a subtidal benthic microalgal community. Estuaries 13(3):219-226

Rysgaard S, Risgaard-Petersen N, Sloth NP (1996) Nitrification, denitrification, and nitrate ammonification in sediments of two coastal lagoons in southern France. Hydrobiologia 329:133-141

Editorial responsibility: Kenneth Heck (Contributing Editor), Dauphin Island, Alabama, USA
Santos MCFV (1996) Intertidal salinity buildup and salt flat development in temperate salt marshes: a case study of the salt flats at the Virginia barrier islands. PhD thesis, University of Virginia, Charlottesville, VA

Seitzinger SP, Sanders RW (1997) Contribution of dissolved organic nitrogen from rivers to estuarine eutrophication. Mar Ecol Prog Ser 159:1-12

Sfriso A, Pavoni B, Marcomini A, Orio AA (1992) Macroalgae, nutrient cycles, and pollutants in the lagoon of Venice. Estuaries 15(4):517-528

Shoaf WT, Lium BW (1976) Improved extraction of chlorophyll $a$ and $b$ from algae using dimethylsulfoxide. Limnol Oceanogr 21:926-928

Solorzano L (1969) Determination of ammonia in natural waters by the phenol hypochlorite method. Limnol Oceanogr 14:799-801

Sundback K, Miles A, Goransson E (2000) Nitrogen fluxes, denitrification and the role of microphytobenthos in microtidal shallow-water sediments: an annual study. Mar Ecol Prog Ser 200:59-76

Turpin DH (1991) Effects of inorganic N availability on algal photosynthesis and carbon metabolism. J Phycol 27: $14-20$

Tyler AC, McGlathery KJ, Anderson IC (2001) Macroalgal mediation of dissolved organic nitrogen fluxes in a temperate coastal lagoon. Estuar Coast Shelf Sci 53: 155-168

Valiela I, Foreman K, LaMontagne M, Hersh D and 7 others (1992) Couplings of watersheds and coastal waters: sources and consequences of nutrient enrichment in Waquoit Bay, Massachusetts. Estuaries 15(4):443-457

Valiela I, McClelland J, Hauxwell J, Behr PJ, Hersh D, Foreman K (1997) Macroalgal blooms in shallow estuaries: Controls and ecophysiological and ecosystem consequences. Limnol Oceanogr 42:1105-1118

Viaroli P, Bartoli M, Bondavalli C, Christian RR, Giordani G, Naldi M (1996) Macrophyte communities and their impact on benthic fluxes of oxygen, sulphide and nutrients in shallow eutrophic environments. Hydrobiologia 329: 105-119

Wessel WW, Tietema A (1992) Calculating gross N transformation rates of ${ }^{15} \mathrm{~N}$ pool dilution experiments with acid forest litter: Analytical and numerical approaches. Soil Biol Biochem 24:931-942

Submitted: June 25, 2001; Accepted: September 6, 2002 Proofs received from author(s): December 10, 2002 